\title{
EDITORIAL
}

\section{Revista Educação (v. 42, n. 3, 2019)}

\author{
Marcos Villela Pereira $(1)$ \\ Pontifícia Universidade Católica do Rio Grande do Sul, Porto Alegre, RS, Brasil.
}

66 ' stamos sendo atacados!” Essa frase, proferida pelo personagem interpretado por Silvero CPereira em Bacurau (MENDONÇA FILHO; DORNELLES, 2019), abre duas dimensões possíveis, se quisermos considerá-la como um enunciado. Por um lado, ela é um ponto de convergência, ela é o dito acerca de um estado da realidade que temos vivido desde há alguns anos, quando uma onda neoconservadora de direita começa a tomar corpo e passa a desferir sistemáticos ataques às instituições democráticas e aos direitos coletivos. É uma constatação, um alarme, o registro de uma evidência, é a voz de um porta-voz que, em certa medida, expressa o sentimento de boa parte dos brasileiros. Por outro lado, é uma conclamação, uma palavra de ordem, uma ideiaforça, na medida em que, ao ser proferida, faz despertar a atenção daqueles que, porventura, ainda não tinham percebido a complexidade e a gravidade da situação. É um chamado, um grito de guerra, um bordão que desencadeia o impulso da tomada de providências.

Em ambos os casos, trata-se de uma incitação ao coletivo. A conjuntura atual das novas tecnologias, da invisibilidade dos sujeitos nas redes sociais, do acuo que temos sofrido pela pressão das políticas públicas, tudo favorece o fechamento do indivíduo em um mundo que, apesar de superconectado, o projeta no isolamento individualista. Presenciamos os acontecimentos, sofremos os efeitos, assistimos aos desmandos contra a humanidade, mas, a despeito disso, parece que as coisas são feitas para que não nos avizinhemos dos enxames, dos bandos e cardumes de tantos outros que também são alvo disso tudo. As iniciativas coletivas emergem para logo serem abafadas pelas forças repressivas e/ou pelo efeito devastador e neutralizador das mídias.

"Estamos sendo atacados!" é o grito que nos acorda, que nos faz tomar consciência do que vem acontecendo, do que tem acontecido, é um registro do estado atual das coisas. "Estamos sendo atacados!" é o alarme dado para que nos unamos em uma ação coletiva e comecemos a produzir uma resistência suficientemente forte como para produzir os desejados efeitos de construção de um outro mundo, que acreditamos ser possível existir. Enguita (1989, p. 7), falando sobre a escola, afirma que a resistência é a "a negativa coletiva em aceitar as exigências e promessas" que nos invadem e nos intoxicam. "Estamos sendo atacados!" é uma constatação e uma declaração de guerra, um chamado à resistência - uma conclamação ao coletivo, para que se recuse a aceitar as exigências e as promessas sob as quais temos sido soterrados.

O filme é de 2019. No momento em que escrevo este Editorial, também estamos assistindo às manifestações no Chile e no Equador, ao resultado das eleições na Bolívia, na Argentina, no Uruguai e na Colômbia, e à crônica dos desmandos no Brasil. Não são poucos os movimentos coletivos que têm eclodido nos últimos anos, especialmente na América Latina, revelando a qualidade da força, a qualidade do poder, o potencial de organização e resistência que temos nas mãos.

Em 2018, em uma ação conjunta e quase simultânea, entre Salvador e Porto Alegre, realizamos o V ALFAeEJA, Encontro Internacional de Alfabetização e Educação de Jovens e Adultos. Por si só, vale dizer que o movimento da EJA se caracteriza pela verve de resistência - com estratégias tributárias a Paulo Freire e a outros trabalhadores da Cultura Popular e da Pedagogia da Libertação, a Educação de Jovens e Adultos é um lócus que agrega sujeitos que, quase por regra, não deveriam estar na escola. Isso porque as regras, quem as têm feito, são justamente "eles", esses que estão nos atacando. E não foi à toa que o tema desse V ALFAeEJA foi "A EJA em contextos de resistências 
e lutas: a garantia do(s) direitos à educação" - experimentamos um espaço coletivo em que foi possível debater não apenas o campo da EJA, mas colocar em análise a conjuntura das adjacências, as implicações da pesquisa, das práticas e das políticas públicas, oportunizando pensar em conjunto ações articuladas entre os diferentes atores, contextos e processos que favorecem a construção de uma negativa coletiva às exigências e promessas que nos têm sido apresentadas como expedientes de dominação.

Este número da Revista Educação oferece ao leitor um dossiê que teve como ponto de partida esse evento. A edição não traz trabalhos apresentados no evento, mas de artigos produzidos pela rede de pesquisadores que se articula em torno do tema e que esteve presente no Encontro. Desafios, brechas, liberdade, políticas, fogo cruzado, grito e esperança são algumas das expressões que aparecem nos títulos dos trabalhos, deixando bem claro que entendemos a pesquisa, o ensino, a prática cultural e a produção de conhecimento como estratégias de luta e resistência, no interior das formações sociais das quais fazemos parte. Brasileiros, estrangeiros, trabalhadores, indígenas, quilombolas, pessoas com deficiência, todos somos adultos comprometidos com as práticas da Educação Popular, que declaramos nossa aliança contra aqueles que estão nos atacando.

$\mathrm{Na}$ sequência, os artigos de demanda contínua não deixam por menos: cada um deles vai, a seu modo, colocar em análise aspectos e dimensões do cotidiano educacional que, em seu conjunto, contribuem para pensar nesse contexto contemporâneo de ataque, luta e resistência. Enfrentamentos e silenciamentos são sucedidos pela estratégia da problematização e pela provocação ao encontro, para desembocar na conectividade dos sujeitos e em práticas de formação. Estratégia e tática, maquinação, articulação de sujeitos e ideias que, de alguma maneira, acreditam que outro mundo é possível. Melhor que esse, sem dúvida - um mundo em que o encontro das diferenças e das singularidades nos desafie a inventar outro modo de vida, que não seja excludente, segregativo e opressor, um mundo que não tenha lugar para práticas fascistas, onde o respeito, as relações democráticas, a cultura popular e a diversidade sejam o princípio da organização da coexistência dos coletivos em que, como diz Foucault (2008), posições díspares permaneçam díspares, ainda que isso demande o contínuo estabelecimento de acordos que o tornem possível.

Boa leitura!

\section{REFERÊNCIAS}

ENGUITA, Mariano F. Educação e teorias da resistência. Educação \& Realidade, Porto Alegre, v. 14, n. 1, p. 3-15, jan./jun. 1989.

FOUCAULT, Michel. O nascimento da biopolítica. São Paulo: Martins Fontes, 2008.

MENDONÇA FILHO, Kleber; DORNELLES, Juliano. Bacurau [Filme-vídeo]. Produção de Emilie Lesclaux, Saïd Ben Saïd e Michel Merkt, direção de Kleber Mendonça Filho e Juliano Dornelles. Recife, Cinemascópio, 2019. 132 min. son. color.

Recebido em: 4/11/2019.

Aprovado em: 5/11/2019.

Publicado em: 21/12/2019.

Endereço para correspondência:

Marcos Villela Pereira

Pontifícia Universidade Católica do Rio Grande do Sul (PUCRS)

Av. Ipiranga 6688, Prédio 08 - Partenon

90619-900, Porto Alegre, RS, Brasil

\section{Autor:}

Marcos Villela Pereira

Doutor em Educação, Pesquisador 1C/CNPq, Professor Titular do Programa de Pós-Graduação em Educação da PUCRS,

Coordenador do CEB/EH/PUCRS - Centro de Ensino e Pesquisa em Contextos e Processos da Educação Básica.

Editor adjunto da Revista Educação.

Orcid: http://orcid.org/0000-0002-3977-5167

E-mail: marcos.villela@pucrs.br 